\title{
28. HYDROTHERMAL CIRCULATION AND INTRAPLATE DEFORMATION: CONSTRAINTS AND PREDICTIONS FROM IN-SITU MEASUREMENTS AND MATHEMATICAL MODELS ${ }^{1}$
}

\author{
Colin F. Williams ${ }^{2}$
}

\begin{abstract}
During ODP Leg 116, three sites were drilled on a transect across two tilted fault blocks in the region of central Indian Ocean intraplate deformation. Well logs and core analyses from these sites, when combined with site survey data, provide detailed information about the physical, chemical, hydraulic, and thermal properties of the $2 \mathrm{~km}$ thick sedimentary sequence. Within the undeformed sediments, heat flow matches the $52 \mathrm{~mW} / \mathrm{m}^{2}$ predicted by cooling plate models for $78 \mathrm{Ma}$ crust. Within $5 \mathrm{~km}$ of a buried reversed fault, heat flow averages $84 \mathrm{~mW} / \mathrm{m}^{2}$ and reaches values as high as $166 \mathrm{~mW} / \mathrm{m}^{2}$. Evidence from downhole temperatures, interstitial water chemistry, and sediment diagenesis establishes the presence of active hydrothermal circulation near the buried fault.

A mathematical model has been developed to study the nature and magnitude of this hydrothermal flow. Basal crustal heat flow is specified as $52 \mathrm{~mW} / \mathrm{m}^{2}$. The possible range of sediment permeabilities is established from porosity logs and core sample permeability measurements. Fault zone and basement permeabilities are allowed to vary, depending upon the particular simulation. The effects of sedimentation and dewatering are included for the 7 my evolution of the deformation structures.

If the underlying oceanic basement is impermeable, the low undeformed sediment permeability (as low as $10^{-18}$ $\mathrm{m}^{2}$ ) retards fluid movement and limits the fluid volume available for upflow along the fault to a value below that necessary for reproducing the observed high heat flow. If the basement is permeable $\left(10^{-14} \mathrm{~m}^{2}\right)$, flow upward from basement along the reverse fault leads to an approximate match with the observed heat flow. This reactivated basement convection requires the presence of low heat flow recharge zones on nearby fault blocks.

An alternative to the permeable basement model is advection of fluid resulting from recent lithospheric reheating. In this case, fluid rises within the permeable, deformed sediments, producing a pronounced heat flow high over the thrust fault before conductive effects appear in the undeformed sediments. However, reheating of the upper crust must have occurred within the last $100,000 \mathrm{yr}$ to match the observed heat flow pattern. Other alternatives, such as high pore pressure faulting, require permeable basement recharge, so that basement circulation remains the most likely explanation for the hydrothermal flow. The prediction of reactivated basement convection can be tested with additional field measurements.
\end{abstract}

\section{INTRODUCTION}

Hydrothermal fluid flow in the oceanic crust is a phenomenon which produces characteristic thermal, geochemical, and biological signals at mid-ocean ridges (Macdonald et al., 1980), island arcs (Yamano and Uyeda, 1988), accretionary prisms (Langseth et al., 1988; Mascle, Moore, et al., 1988) and up to 70 Ma sedimented oceanic crust (Anderson et al., 1977). Direct and indirect observations of hydrothermal systems are increasingly common, and the processes and parameters of these systems have been constrained by a number of mathematical models (e.g., Williams et al., 1974; Fehn et al., 1983). However, despite this substantial progress, integrated geophysical, geochemical, and geological studies are only now providing the information necessary for understanding hydrothermal systems in detail. Observations made during Ocean Drilling Program (ODP) Leg 116, while far from a comprehensive ideal, constitute an adequate basis for coupling core and in situ measurements with quantitative modeling of hydrothermal circulation in the zone of intense compressional crustal deformation within the central Indian Ocean.

This deformation is thought to result from buckling of the oceanic lithosphere after the uplift of the Himalayas in the "hard" continent-continent collision between India and Eur-

\footnotetext{
${ }^{1}$ Cochran, J. R., Stow, D.A.V., et al., 1990. Proc. ODP, Sci. Results, 116: College Station, TX (Ocean Drilling Program).

2 Borehole Research Group, Lamont-Doherty Geological Observatory, Columbia University, Palisades, NY (now at U.S. Geological Survey, Branch of Tectonophysics, MS 923, 345 Middlefield Road, CA 94025, U.S.A.
}

asia in the Miocene (Weissel et al., 1980; Cochran, this volume). Early observations on the style and magnitude of this deformation noted the correlation of anomalous, long wavelength basement undulations $(100-300 \mathrm{~km})$ with smallscale, high-angle reverse faults (5-20 km spacing) and geoid anomalies (Eittreim and Ewing, 1972; Weissel et al., 1980; Fig. 1). The east-trending basement undulations lie in a region characterized by variable high heat flow $\left(48-155 \mathrm{~mW} / \mathrm{m}^{2}\right.$, Geller et al., 1983) and a high level of historical, intraplate seismicity (Stein and Okal, 1978). Geller et al. (1983), in the first comprehensive marine geophysical study of this deformation zone, provided some general constraints on the possible source of this high heat flow and its relationship to deformation processes. A number of their recorded nearsurface temperature profiles display nonlinear gradients, and, through a careful analysis of the possible processes that could account for these nonlinear gradients, Geller et al. (1983) concluded that the nonlinearity reflected vigorous pore water advection up through the seafloor. In addition, the resulting averages of heat flow measurements throughout the region exceed the predicted cooling oceanic plate values by approximately $30 \mathrm{~mW} / \mathrm{m}^{2}$ (Weissel et al., 1980; Geller et al., 1983;, Hobart, unpublished data). These observations, when combined with the related gravitational and seismological data, verified the importance of hydrothermal flow within this deformation zone but also left a number of fundamental questions unresolved.

For example, is fluid flow confined to high permeability reverse faults or is it active in both deformed and undeformed sediments? Is the circulation a simple discharge/recharge 
N

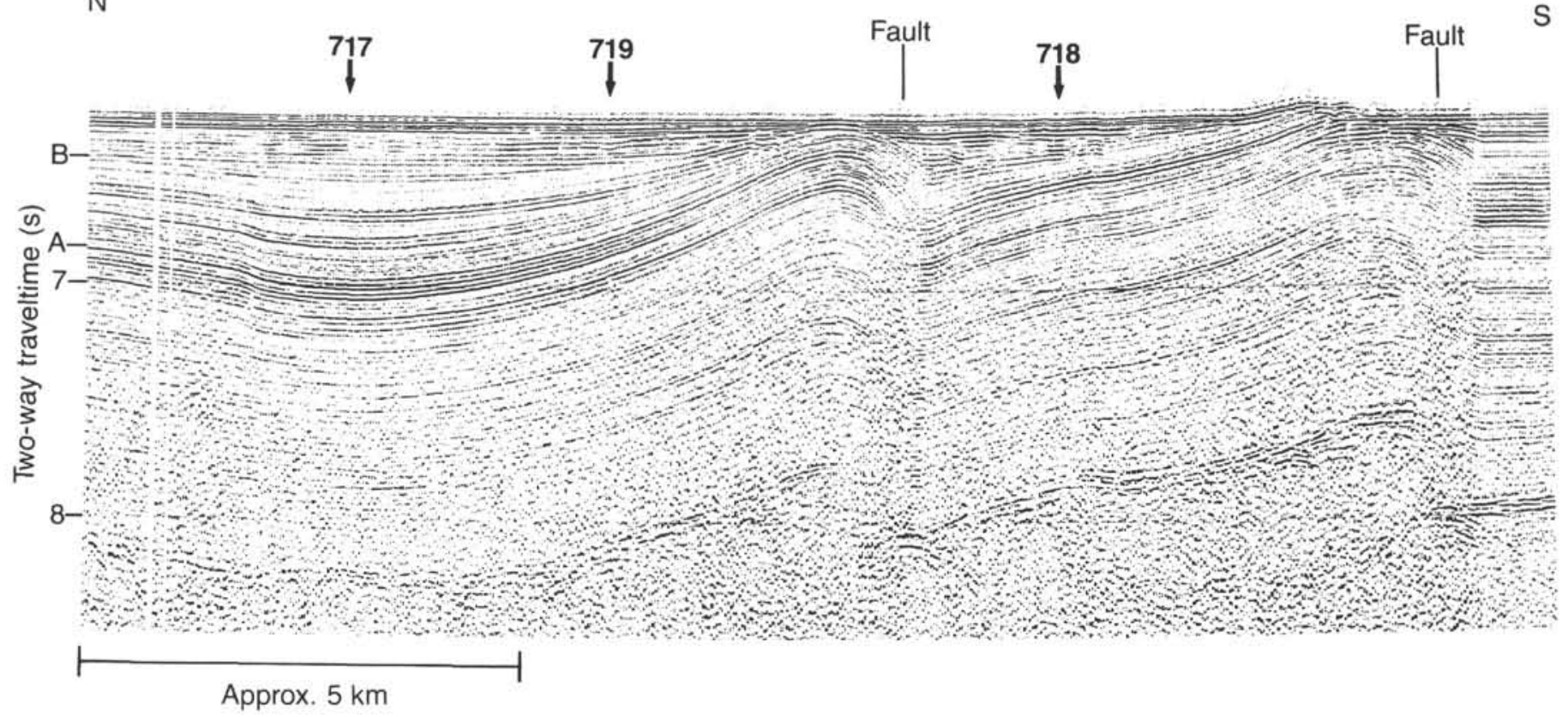

Figure 1. Single channel seismic section through the Leg 116 drill sites, showing sediment deformation and faulting due to the intraplate compression.

system or does sediment dewatering lead to a predominantly advective system? Is the convection driven by a basal conductive heat flux consistent with cooling plate models for oceanic lithosphere or is there a deep lithospheric heat source that accounts for the high average heat flow value? Is fluid flow confined to the sediments or is a reactivated permeable basement convection system involved?

The pre-drilling site survey and the Leg 116 drilling plan were devised to provide answers to these and other questions regarding the history, thermal state, tectonics, and fluid flow processes of this intraplate deformation zone (Cochran, Stow, et al., 1989). The following discussion summarizes the relevant site survey and drilling results and presents a mathematical model of heat and fluid transport within the study area. Modeling results eliminate some of the possible fluid flow processes mentioned above, and allow us to determine

1. The importance of faults and fractures to the permeability structure of the sediments and upper crust,

2. The relative contributions of sediment dewatering and fluid circulation to the regional heat flow pattern,

3. The significance of basement permeability in the circulation system,

4. The temporal response of the system to a deep lithospheric heat source, and

5. The implications of porosity and other physical properties measurements for anomalous fluid pressures.

The final results leave two quantitatively constrained alternatives for the hydrothermal circulation resulting from deformation. The first is a reactivated basement convection system, and the second is fluid advection in response to recent lithospheric reheating.

\section{SITE SURVEY AND DRILLING RESULTS RELATED TO HEAT AND FLUID FLOW}

The Conrad site survey for Leg 116 included a closelyspaced grid of heat flow stations covering the folded and thrusted sediments of two fault blocks which lie atop a prominent, long wavelength basement high (Figs. 1 and 2; Cochran, Stow, et al., 1989). The resulting contoured heat flow pattern shows a trend of heat flow highs running roughly parallel to, but offset from, a buried reverse fault (Fig. 3). These values clearly demonstrate the association of high heat flow with fault zones and suggest that, while these faults probably act as high permeability conduits for fluid flow, the deformed sediments adjacent to the faults are also an integral part of the local plumbing system. It should be noted, however, that all of the temperature gradients recorded during this survey were linear, in contrast to many of the measurements obtained by Geller et al. (1983).

During Leg 116 , three sites $(717,718,719)$ were drilled on a north-south transect across the two tilted fault blocks (Fig. 2 and Cochran, Stow, et al., 1989). The dominant lithologies have been divided into five main stratigraphic units of Bengal Fan sediments, ranging from Holocene to early Miocene age. These are

Unit I: Holocene to latest Pleistocene age muds and mud turbidites. This unit typically extends to only $5 \mathrm{~m}$ below seafloor (mbsf).

Unit II: Late Pleistocene micaceous silty turbidites with intervening thin mud layers and calcareous clays.

Unit III: Pleistocene and late Pliocene mud turbidites with interbedded pelagic clays.

Unit IV: Late Miocene to early Pliocene alternating sections of silt turbidites and mud turbidites.

Unit V: Late to early Miocene silt and silty mud turbidites with variable thickness interbeds of mud turbidites and pelagic clays.

These units are present at all three sites, with subunits of detailed lithologic variations identifiable within the thick sedimentary sections of Sites 717 and 719 (Fig. 4). Despite the scarcity of recovered samples and extensive reworking, approximate sedimentation rate curves have been developed for 


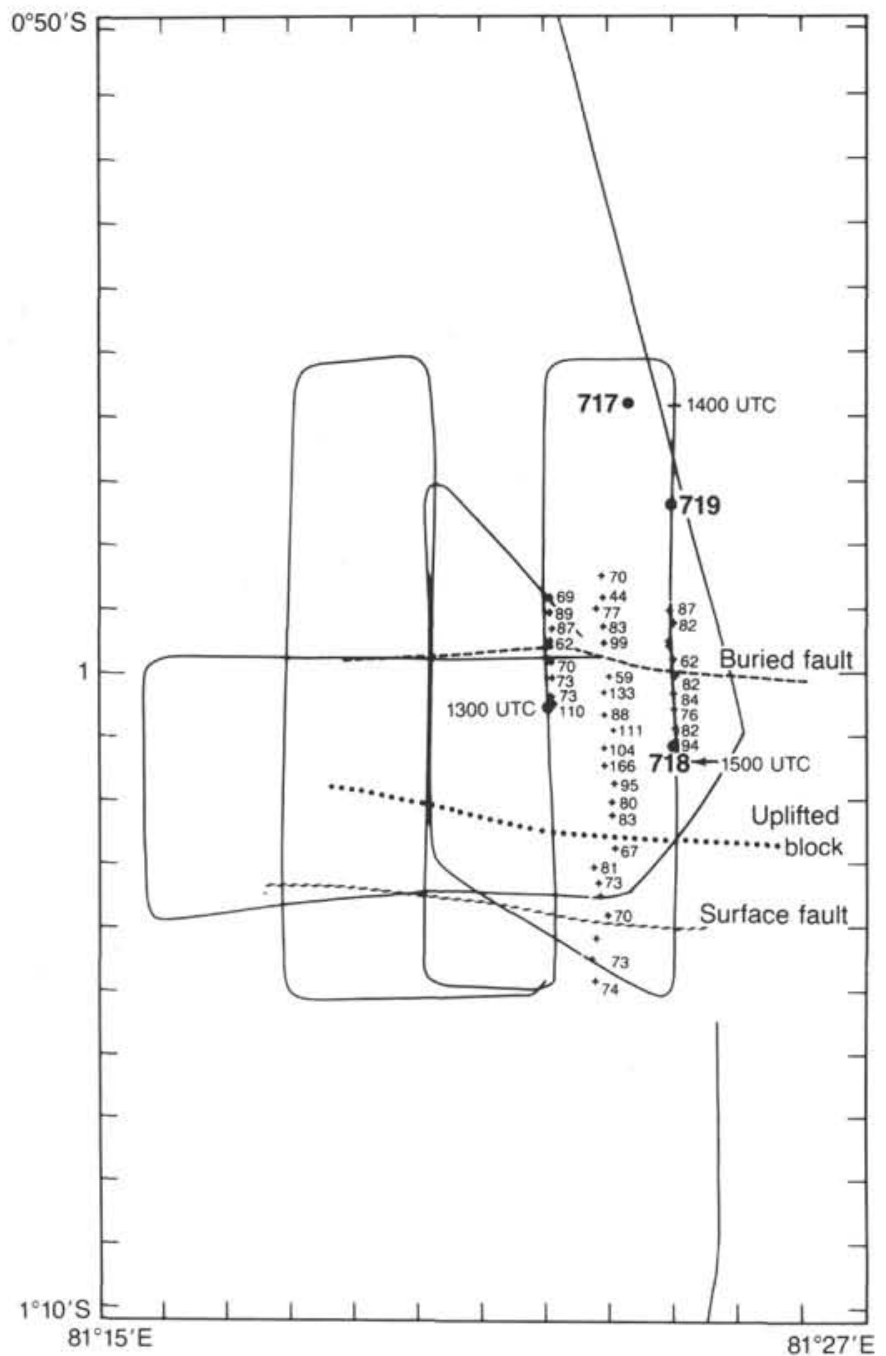

Figure 2. Conrad 2706 navigation track showing location of the Leg 116 sites, single channel seismic lines and heat flow stations (values in $\mathrm{mW} / \mathrm{m}^{2}$ ).

all three sites (Fig. 5). A quantitative history of sedimentation and deformation within the study area follows from the combination of the sedimentation rate curves with the observation that the main thrust fault has been moving at a relatively constant rate $(60 \mathrm{~m} / \mathrm{m} . \mathrm{y}$.) over the past $7.5 \mathrm{Ma}$ (Cochran, Stow, et al., 1989).

Sediment physical properties were determined from wireline logging and core measurements. Logs were run in Holes $718 \mathrm{C}, 718 \mathrm{E}$, and $719 \mathrm{~B}$. Hole $718 \mathrm{C}$ was logged from 100 to 557 mbsf with Schlumberger Well Services combinations of a digital, long-spaced sonic velocity tool (LSS), a phasor, dual induction resistivity tool (DIT), a natural gamma-ray spectroscopy tool (NGT), a lithodensity tool (LDT) (for bulk density and photoelectric capture cross section measurements), and an induced gamma-ray spectroscopy logging tool (GLT) (see "Explanatory Notes" chapter in Cochran, Stow, et al., 1989; and Serra, 1984). Hole $718 \mathrm{E}$ was logged from 173 to $950 \mathrm{mbsf}$ with the LSS, DIT, and NGT, and Hole 719B was logged from 87 to 450 mbsf with the LSS, DIT, NGT, GLT, LDT, and a compensated neutron porosity tool (CNT). Despite the fact that Site 717 was not logged and that core recovery was extremely poor $(<10 \%)$ within the silt-rich intervals, continuous sediment physical properties profiles can be traced

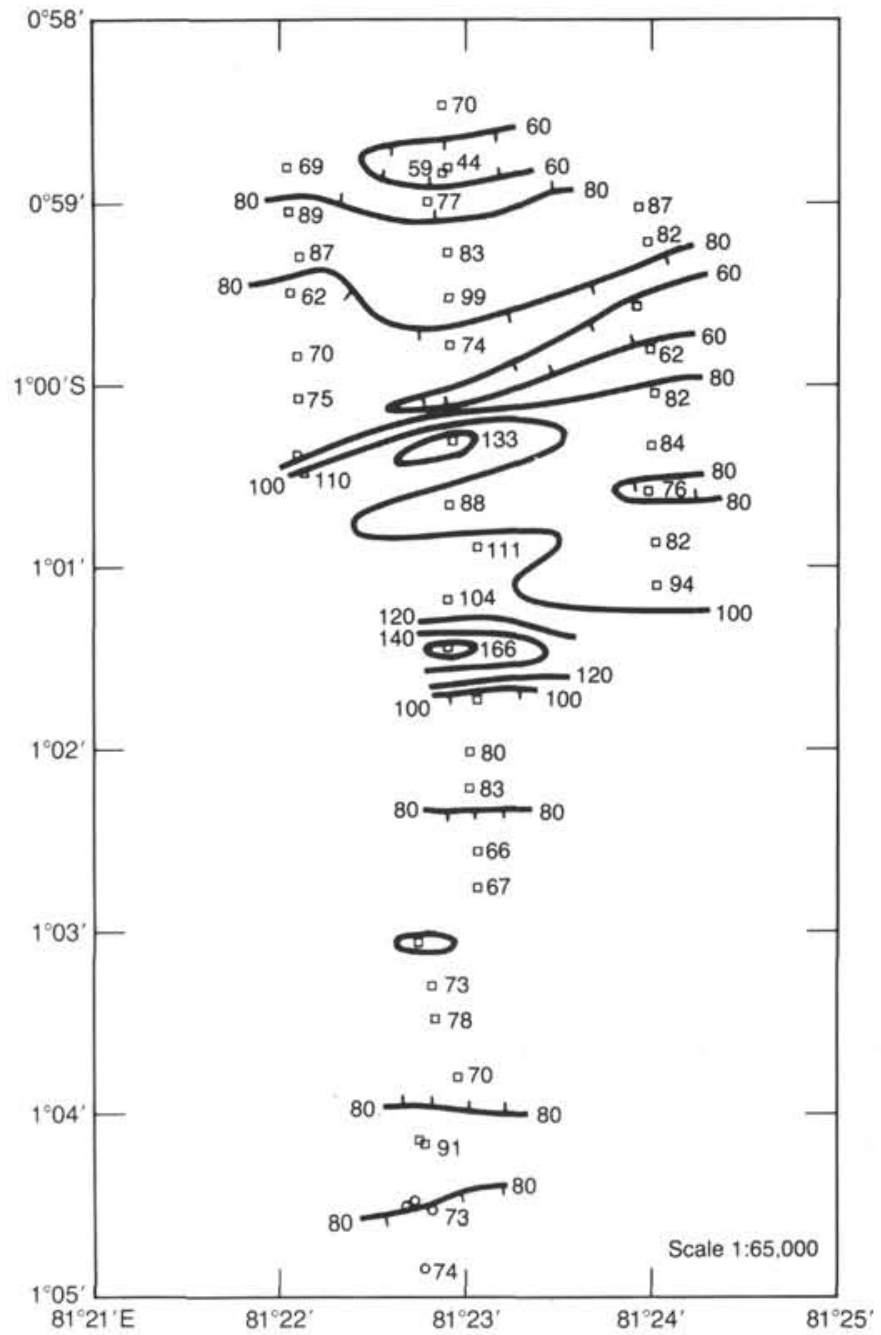

Figure 3. Heat flow contour map showing the fault-paralleling pattern of high heat flow (values in $\mathrm{mW} / \mathrm{m}^{2}$ ).

through all three sites. The predominant lithologic variation, clay vs. silt content, shows up in the resistivity, density, sonic velocity, and neutron porosity curves. Intervals of high silt content are generally of lower porosity and higher density, velocity, and resistivity compared to the intervals of high clay content (Fig. 6). Alternating clay-rich and silt-rich turbidites and their physical properties are thus identifiable from the logs alone, providing information in zones of poor core recovery.

Over the intervals mentioned above, the logs yield a continuous record of sediment physical properties, such as density, sonic velocity, resistivity, and porosity. For depth intervals without logging data, these properties are available from core measurements, since the core and logging measurement techniques have been compared and calibrated (see Wetzel et al., this volume). Additionally, two physical properties which are not measured directly with well logging tools, thermal conductivity and permeability, have been measured on a number of core samples (Wetzel et al., this volume). Even though the permeability data are from a small number of predominantly clay-rich samples, they serve as valuable constraints on both changes in permeability with depth and the lowest expected in situ values. The accuracy of the porosity and permeability model developed below is shown by its general agreement with these measurements. True in situ 


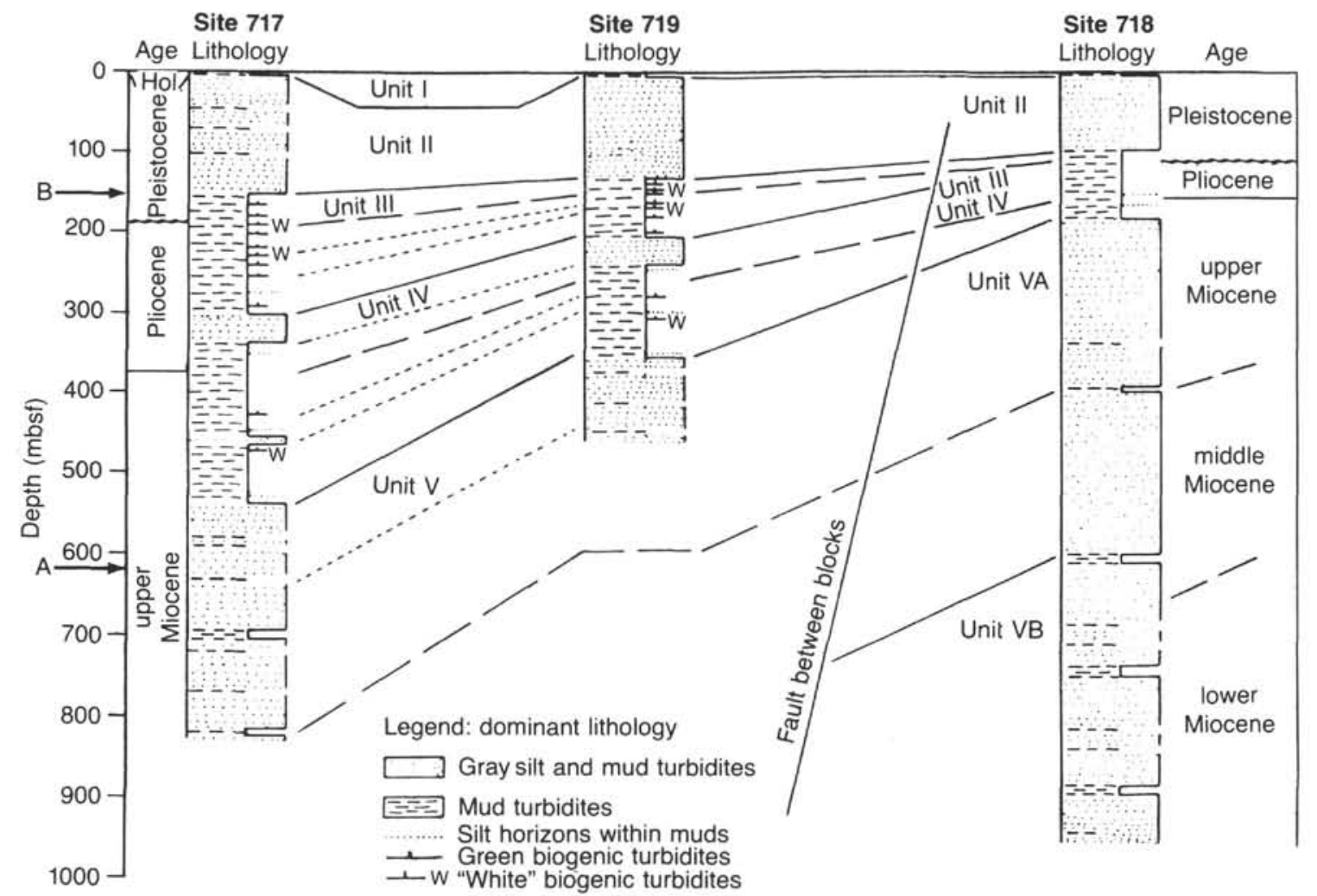

Figure 4. Stratigraphic section through the Leg 116 drill sites. Note the attenuated thickness of lithologic Units III and IV south of the buried reverse fault.

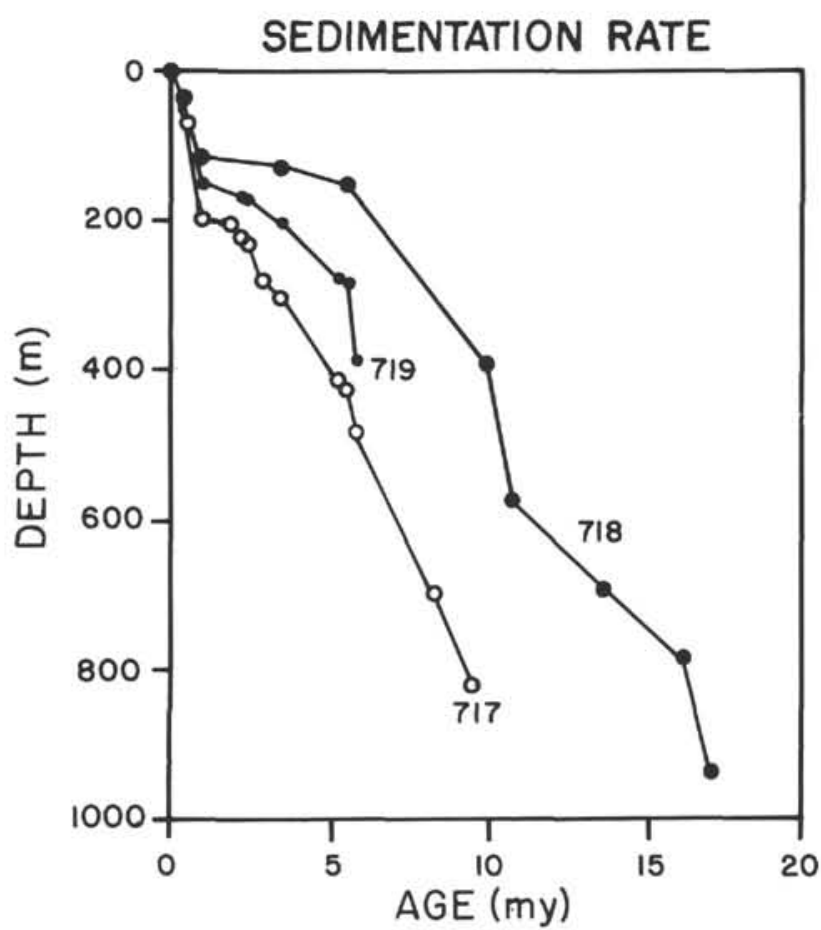

Figure 5. Sedimentation rates for Sites 717,718 , and 719 from Cochran, Stow, et al. (1988). The rates are not corrected for compaction effects. permeabilities are unknown, but average values for these sediment types and modeling results are in fair agreement.

Confirmation of the hydrothermal flow predicted by surface heat flow measurements follows from downhole temperatures and interstitial water chemistry. Temperatures recorded in Holes 717C and 719A, when combined with core thermal conductivity measurements, yield heat flow values of approximately $50 \mathrm{~mW} / \mathrm{m}^{2}$ for both sites, values close to the 52 $\mathrm{mW} / \mathrm{m}^{2}$ predicted for $78 \mathrm{Ma}$ oceanic crust (Parsons and Sclater, 1977). At Site 718, most of the temperature measurements were unreliable because of equipment failures and inadequate deployment of the temperature probe, but the few reliable measurements are highly variable, a result consistent with fluid flow in the vicinity of the borehole (Cochran, Stow, et al., 1989).

Variations in interstitial water chemistry at Sites 717 and 719 follow expected trends for diagenetic alteration in the absence of extensive fluid flow. At Site 718, profiles of magnesium $(\mathrm{Mg})$ and sulfate $\left(\mathrm{SO}_{4}\right)$ concentrations vs. depth in the section above 200 mbsf show mixing between a warm, low $\mathrm{Mg}$ and $\mathrm{SO}_{4}$ content fluid and cold, high $\mathrm{Mg}$ and $\mathrm{SO}_{4}$ content seawater (Boulegue et al., this volume). This observation is consistent with upflow of basement-altered pore water (Gieskes et al., 1989) and its interaction in near-surface convection systems with ocean bottom water. These observations of elevated temperatures due to fluid flow are supported by fission-track analysis of detrital apatites (Corrigan and Crowley, this volume).

\section{POROSITY AND PERMEABILITY STRUCTURE}

Given the importance of accurately determining the porosity and permeability distribution within tilted fault blocks, the compressional wave velocity, bulk density, resistivity, and neutron porosity well $\log$ measurements were analyzed for the 


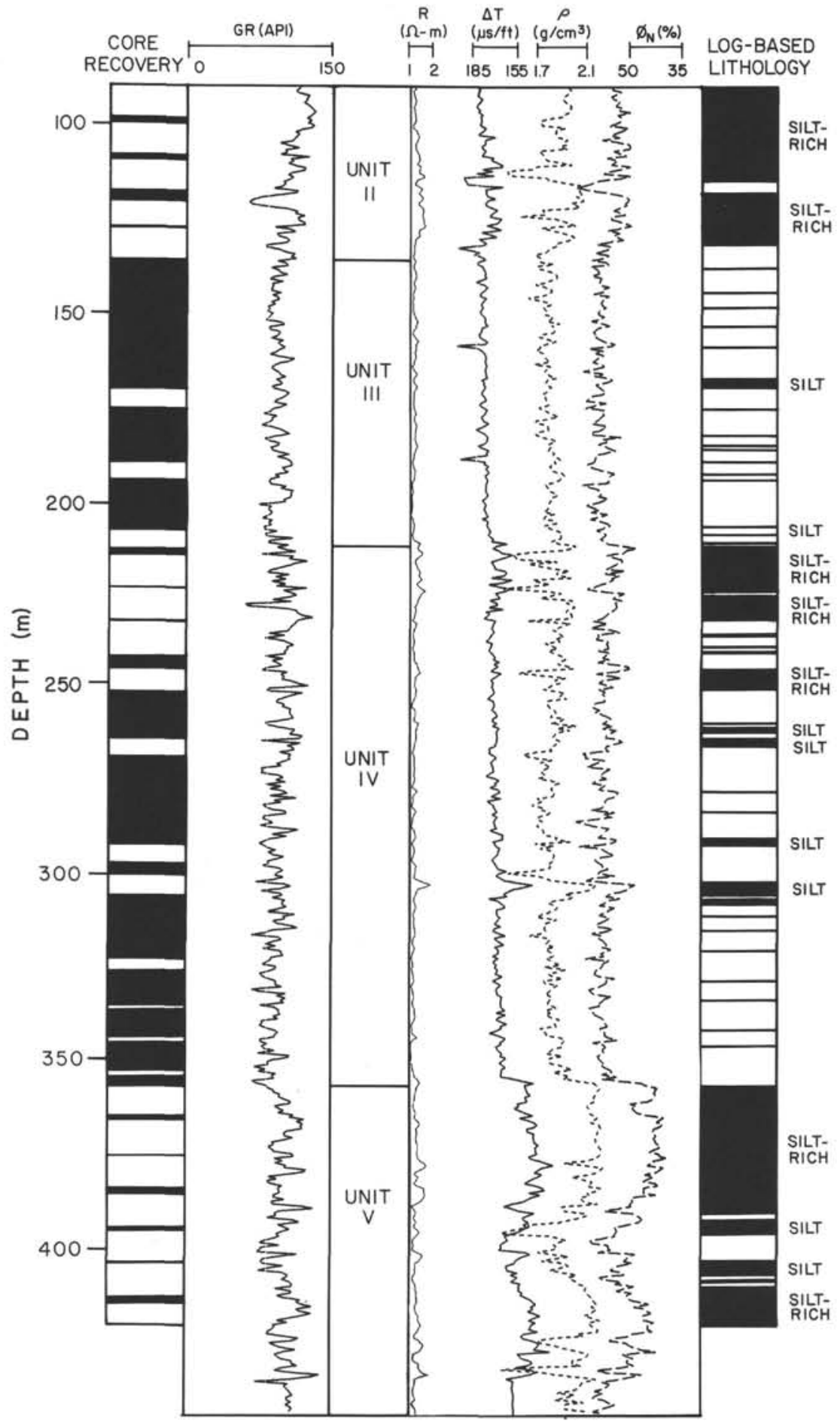

Figure 6. Composite logs from Hole 719B. The curve abbreviations are as follows: GR = natural gamma radiation in API units; $R=$ resistivity in ohm-m; $\Delta T=$ compressional wave slowness in $\mu \mathrm{s} / \mathrm{ft} ; \rho=$ Bulk density in $\mathrm{g} / \mathrm{cm}^{3} ; \phi_{\mathrm{N}}=$ neutron porosity in percent. Note the correlation of log response with lithology and core recovery.

most consistent method of determining porosity. Jarrard et al. (1989), in a study of logging results in terrigenous, high porosity sediments drilled during ODP Leg 105 in the Labrador Sea, found that an application of Archie's porosityresistivity relationship (Archie, 1942) was the most accurate technique for estimating true porosity. Other approaches, such as Raymer et al.'s (1980) model relating porosity to sonic velocity, failed to match the porosities measured on core samples (Jarrard et al., 1989).

In contrast to these results, logging data from Sites 718 and 719 yield a completely opposite correlation. As described in Wetzel et al. (this volume), the resistivity data are relatively featureless and only weakly correlate with porosity variations indicated by both core and other log measurements. The 
neutron porosity and density curves overestimate the true porosity because of problems with tool stand-off in the rugose boreholes (Serra, 1984). However, the long-spaced sonic tool is less sensitive to hole shape and application of Raymer et al.'s (1980) equations to the well $\log$ sonic velocities yielded reliable correlations of log-derived porosity with reboundcorrected core porosities (Wetzel et al., this volume). The Raymer equations are

$$
\begin{gathered}
\mathrm{V}=(1-\phi)^{2} \mathrm{~V}_{\mathrm{m}}+\phi \mathrm{V}_{\mathrm{f}}(\phi \leq 0.37) \\
\mathrm{V}=0.1 \mathrm{~V}_{1} \mathrm{~V}_{2} /\left(\mathrm{V}_{1}(\phi-0.37)-\mathrm{V}_{2}(\phi-0.47)\right) \\
(0.37 \leq \phi \leq 0.47) \\
1 / \rho \mathrm{V}^{2}=\phi / \rho_{\mathrm{f}} \mathrm{V}_{\mathrm{f}}^{2}+(1-\phi) / \rho_{\mathrm{m}} \mathrm{V}_{\mathrm{m}}^{2}(\phi \geq 0.47)
\end{gathered}
$$

where $\phi$ is the porosity, $\mathrm{V}$ is the bulk rock sonic velocity, $\mathrm{V}_{\mathrm{m}}$ is the matrix velocity, $V_{f}$ is the fluid velocity, $V_{1}$ is the sediment velocity for a $\phi$ of $0.37, \mathrm{~V}_{2}$ is the velocity for a $\phi$ of 0.47 , and $\rho, \rho_{\mathrm{m}}$, and $\rho_{\mathrm{f}}$ are the bulk, matrix, and fluid densities, respectively. For the clay-rich sediments of Units III, IVB, IVD, and parts of V, Equations 2 and 3 were applied with matrix density and velocity of $2.75 \mathrm{~g} / \mathrm{cm}^{3}$ and $5.5 \mathrm{~km} / \mathrm{s}$, respectively. For the silt-rich sediments, porosity was estimated from Equation 2; values for $\mathrm{V}_{1}$ and $\mathrm{V}_{2}$ were determined by comparing core porosities to $\log$ velocities. Despite the well-documented limitations of the Raymer approach (Jarrard et al., 1989), this technique worked well in Holes $718 \mathrm{E}$ and 719B (Fig. 7). The success of different porosity models in different regions illustrates the complications inherent in the poorly understood relationships between sediment physical properties and porosity.

Using the nearly continuous porosity curves from Sites 718 and 719 , an average porosity-depth function was determined separately for the clay-rich sediments and the silt-rich sediments through least-squares curve-fits to an exponential decrease with depth. The resulting relationships are as follows:

$$
\begin{aligned}
& \text { Silt-rich: } \phi(z)=0.529 \mathrm{e}^{-0.00072 z} \\
& \text { Clay-rich: } \phi(\mathrm{z})=0.578 \mathrm{e}^{-0.00073 z}
\end{aligned}
$$

where $\mathrm{z}$ is depth in meters. The decrease in porosity with depth for the silt-rich sediments is approximately the same as that for the clay-rich sediments, a result inconsistent with the general observation that shale porosity decreases more rapidly with depth than sand porosity (Palciauskas, 1986). There are two possible reasons for this. First, it may be that the silty sediments of Unit V are distinctly different from those of Units II and IV. This would lead to an incorrect estimate for $\phi(\mathrm{z})$, but a difference in porosity of approximately $10 \%$ by 800 mbsf is unlikely. Second, it is possible that the slight sediment undercompaction noted by Wetzel (this volume) is more pronounced in the low permeability clays than in the relatively permeable silts.

No in situ permeability measurements were made during Leg 116, so the best estimate of permeability is derived from the empirical Kozeny-Carman porosity-permeability relationship, constrained by the 32 core permeability measurements ( 28 on clay-rich sediments and 4 on silt-rich sediments) made by Wetzel (this volume). The Kozeny-Carman relationship is a well-established method for relating porosity to permeability in sediments of uniform grain size (Bourbie et al., 1987). This relationship can be expressed as

$$
k=\phi^{3} d_{g}^{2} / 180\left(1-\phi^{2}\right)
$$

where $\mathrm{k}$ is the permeability, $\mathrm{d}_{\mathrm{g}}$ is the average grain diameter, and 180 is an empirically-derived tortuosity constant. Since neither $d_{g}$ nor the true tortuosity factor are known for these sediments, a calibration value, $\mathrm{k}_{0}$, was determined for the undisturbed sediments by taking reference values of permeability for a given porosity. This calibration value then was used in Equation 6 as a substitute for $d_{g}{ }^{2} / 180$. For the silt-rich sediments, $\mathrm{k}_{0}$ is approximately $10^{-14} \mathrm{~m}^{2}$ for $\phi=0.53$, and for the clay-rich sediments, $\mathrm{k}_{0}$ is approximately $10^{-16} \mathrm{~m}^{2}$ for $\phi=$ 0.58 . This approach yields a permeability relationship of the form

$$
\mathrm{k}(\phi)=\mathrm{ck}_{0} \phi^{3} /\left(1-\phi^{2}\right)
$$

where $\mathrm{c}$ is proportionality constant. The permeability values reported by Wetzel (this volume) range from $10^{-14}$ to $10^{16} \mathrm{~m}^{2}$ for the silts and $10^{-16}$ to $10^{-8} \mathrm{~m}^{2}$ for the clays, results which are generally consistent with the derived relationship.

\section{The Mathematical Model}

Heat and fluid flow within this tilted fault block system was modeled using a modified version of PT, an integral finite difference method (IFDM) program that solves for simultaneous mass and heat transport within a one-, two-, or threedimensional, heterogeneous porous medium (Narasimhan and Witherspoon, 1976; Bodvarsson, 1982). The relevant conservation equations are expressed in integral form as follows:

\section{Mass Conservation}

$$
-\int_{A} \rho V_{d} \cdot \mathbf{n} d A+\int_{V} G_{f} d V=\frac{\partial}{\partial t} \int_{V} \phi \rho d V
$$

Energy Conservation

$$
\begin{aligned}
& -\int_{A} C_{f} \delta T V_{d} \cdot \mathbf{n} d A+\int_{A} \lambda \nabla T \cdot n d A \\
& +\int_{V} G_{f} d V=\frac{\partial}{\partial t} \int_{V} \rho e_{f} d V
\end{aligned}
$$

where $\rho$ is fluid density, $\mathrm{V}_{\mathrm{d}}$ is darcy velocity, $\mathrm{n}$ is unit outer normal, $A$ is surface area, $G_{f}$ is mass rate of fluid production, $\mathrm{V}$ is volume, $\phi$ is porosity, $\mathrm{C}_{\mathrm{f}}$ is volumetric specific heat, $\delta \mathrm{T}$ is temperature at the surface segment, $\mathrm{dA}$ is thermal conductivity, $G_{n}$ is rate of energy production per unit volume, and $e_{f}$ is internal energy of the fluid.

The darcy velocity is computed from Darcy's Law,

$$
\mathbf{V}_{\mathrm{d}}=-\frac{\mathrm{k}}{\mu}(\nabla \mathrm{p}-\rho \mathrm{g})
$$

and viscosity and fluid density are calculated from polynomial functions of temperature and pressure. The right-hand side of Equation 8 is determined from

$$
\frac{\partial}{\partial \mathrm{t}} \int_{\mathrm{V}} \phi \rho \mathrm{dV}=\mathrm{V} \phi \rho\left[\beta_{\mathrm{t}} \frac{\partial \mathrm{p}}{\partial \mathrm{t}}-\alpha_{\mathrm{t}} \frac{\partial \mathrm{T}}{\partial \mathrm{t}}\right]
$$




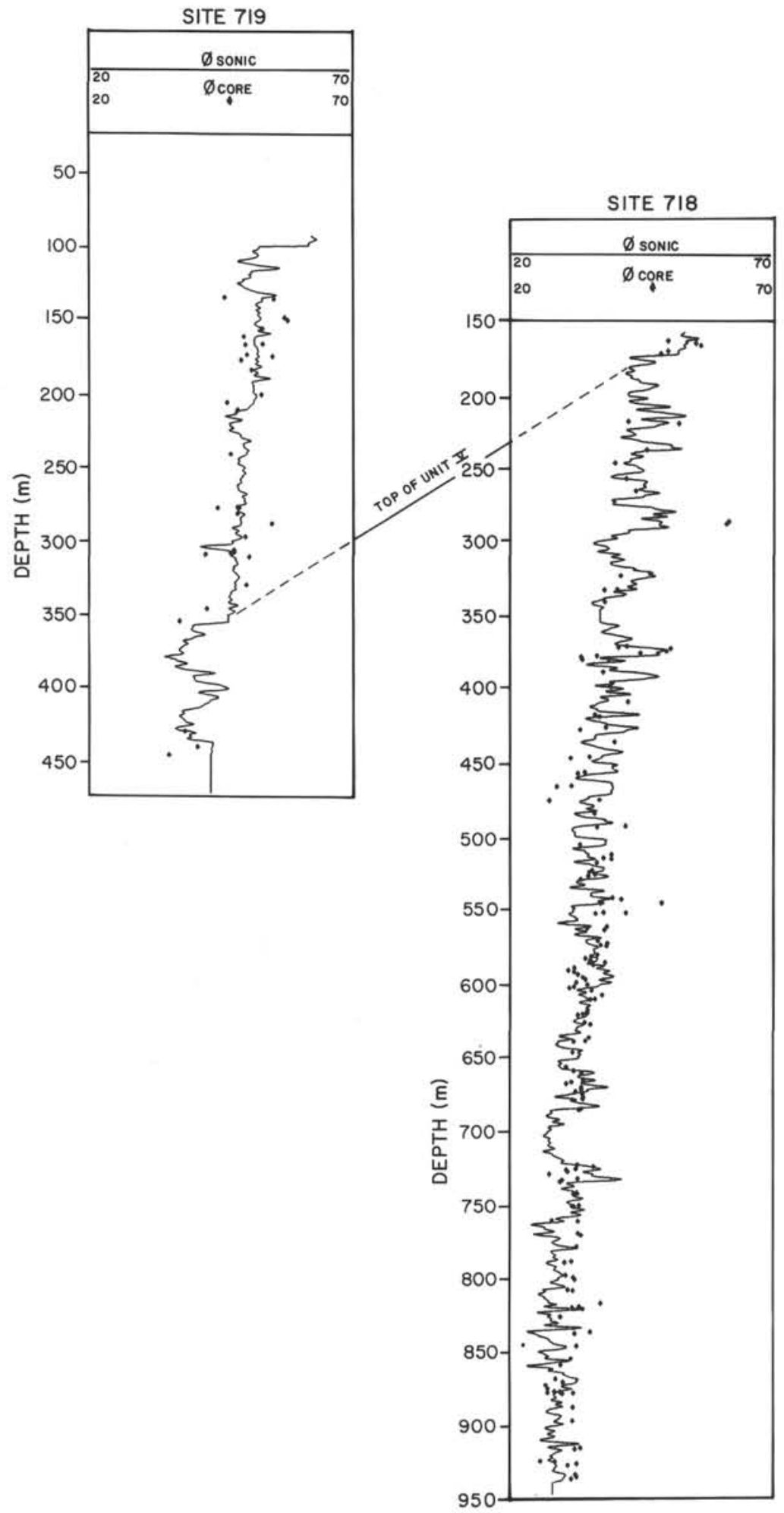

Figure 7. Porosity derived from sonic velocity logs according to the Raymer et al. (1980) relations (Equations 1-3) for Sites 718 and 719.

where $\beta_{\mathrm{t}}$ is the total compressibility and $\alpha_{\mathrm{t}}$ is the total thermal expansivity. Detailed descriptions of the IFDM technique and PT can be found in Narasimhan and Witherspoon (1976) and Bodvarsson (1982). The PT code has been used to study hydrothermal convection in oceanic (Williams et al., 1986) and continental (Tsang and Doughty, 1985; Williams and Narasim- han, 1989) settings involving igneous, metamorphic, and sedimentary rocks.

For this modeling study the mesh of volume elements is a two-dimensional slice through the Leg 116 drill sites across the two tilted fault blocks (Fig. 8). The northern boundary is located near Site 717 at the center of the flat-lying, unde- 


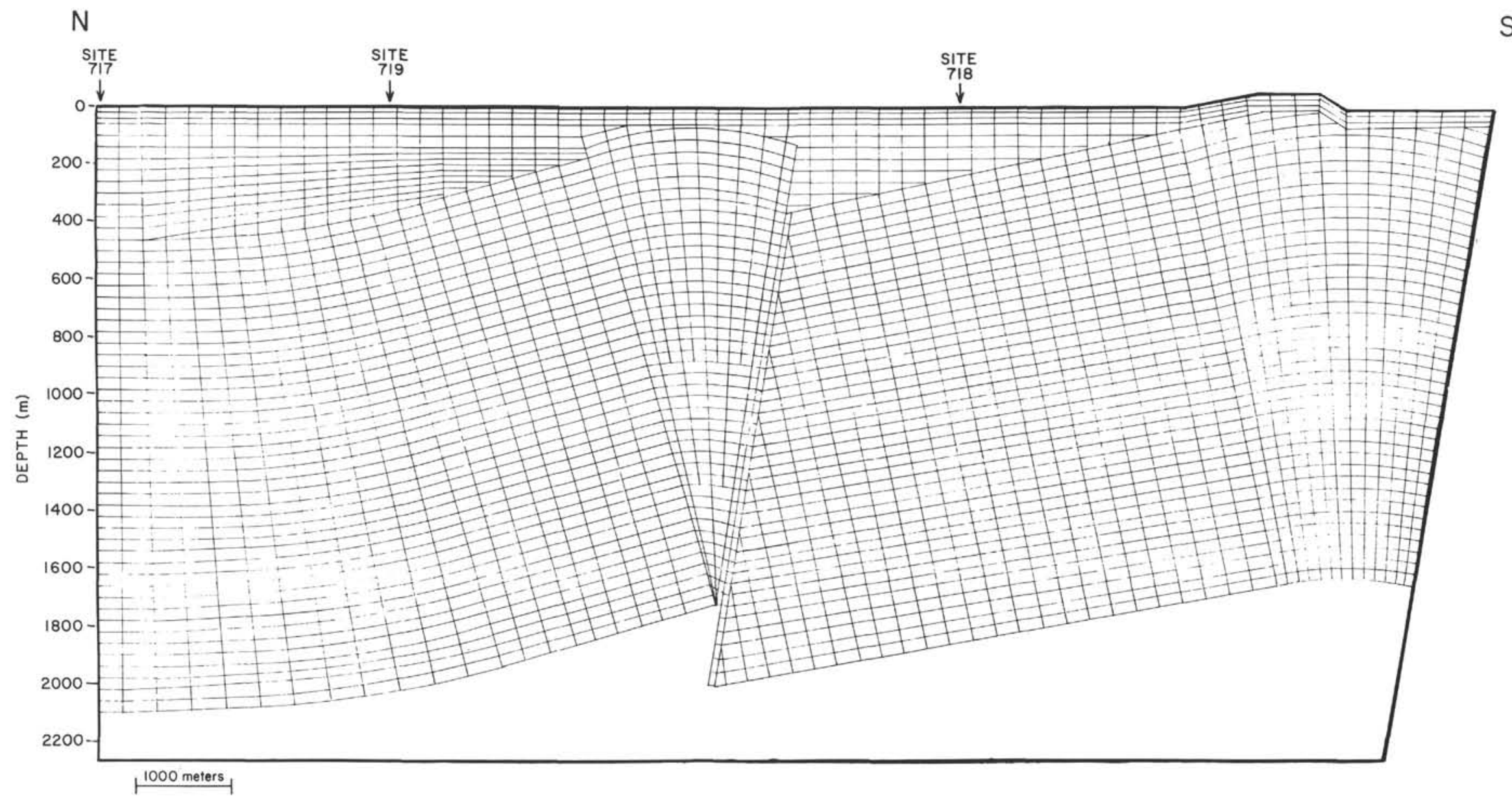

Figure 8. Cross section of the nodal mesh used in the heat and fluid flow simulations. Site locations are noted along the top. 
formed sedimentary sequence north of the buried reverse fault. This boundary is considered to be a plane of symmetry in the rotated fault block system and is closed to heat and fluid flow. The southern boundary is located along the plane of the surface fault, with boundary conditions varying with different fault properties specifications. The upper boundary is the seafloor, for which a constant temperature and pressure are specified, and the lower boundary is located within the oceanic basement, which is specified as impermeable except for the permeable basement simulations discussed below. The sedimentary sequence is modeled with 2614 volume elements of 42 possible material types, each with its own permeability, porosity, and thermal conductivity.

In addition to the porosity and permeability structure discussed above, the basic includes two additional attributes: (1) a basal heat flux of $52 \mathrm{~mW} / \mathrm{m}^{2}$ across the lower boundary and (2) a separate permeability for both the buried and exposed faults.

\section{Simulation Results}

Compressional deformation of the oceanic lithosphere in the central Indian Ocean has been relatively continuous over the past $7 \mathrm{Ma}$. In this period, approximately $600 \mathrm{~m}$ of sediments has been deposited in the Leg 116 study area, and the buried reverse fault offset has reached approximately $400 \mathrm{~m}$. Thus, hydrothermal circulation is part of an evolving system, with simultaneous sedimentation and faulting affecting both heat and fluid flow. In order to gain a quantitative understanding of these dynamic processes, two parallel simulation paths were followed. The first, a static approach, models the 7 my system evolution with an elemental mesh fixed to the present dimensions and physical properties of the tilted fault blocks. The second, a dynamic approach, models the system from an initial unfaulted block through faulting, sedimentation, and compaction over the following $7 \mathrm{~m} . \mathrm{y}$.

\section{Static Simulations}

The first static simulation calculates heat and fluid flow in the sediments using the Kozeny-Carman permeability structure given above but without any separate fault permeability or permeable basement. After 7 m.y., the surface heat flow profile (Fig. 9) shows only a slight deviation from the conductive background heat flow. This result is consistent with the low sediment permeability but falls far below the pattern observed in the heat flow data. Figure 10 shows the profile from a simulation that includes a buried reverse fault having a permeability of $10^{-14} \mathrm{~m}^{2}$. The width of the fault zone is specified as $500 \mathrm{~m}$. Advection of fluid along the fault plane leads to a bulge in heat flow over the fault and slight depressions in heat flow to the north and south. If the permeability of the clay-rich layers is raised by a factor of 10 (one order of magnitude lower than the silt permeability), then the heat flow high narrows to a value of $60 \mathrm{~mW} / \mathrm{m}^{2}$ while the depressions to the north and south deepen (Fig. 11).

A further increase in the fault permeability simply narrows and accentuates the fault-centered heat flow high. The explanation for this result follows from consideration of the low bulk sediment permeability. In a static system, advection along and near the reverse faults is limited to the amount of fluid recharge to the fault surface. Without an additional temperature or pressure driving force, the pore fluid will not circulate much faster than it does in the system if the high permeability fault is absent. Accurate modeling of these forces requires dynamic system simulations.

\section{Dynamic Simulations}

One of the likely sources for additional fluid flow is sediment dewatering resulting from compaction and deforma-

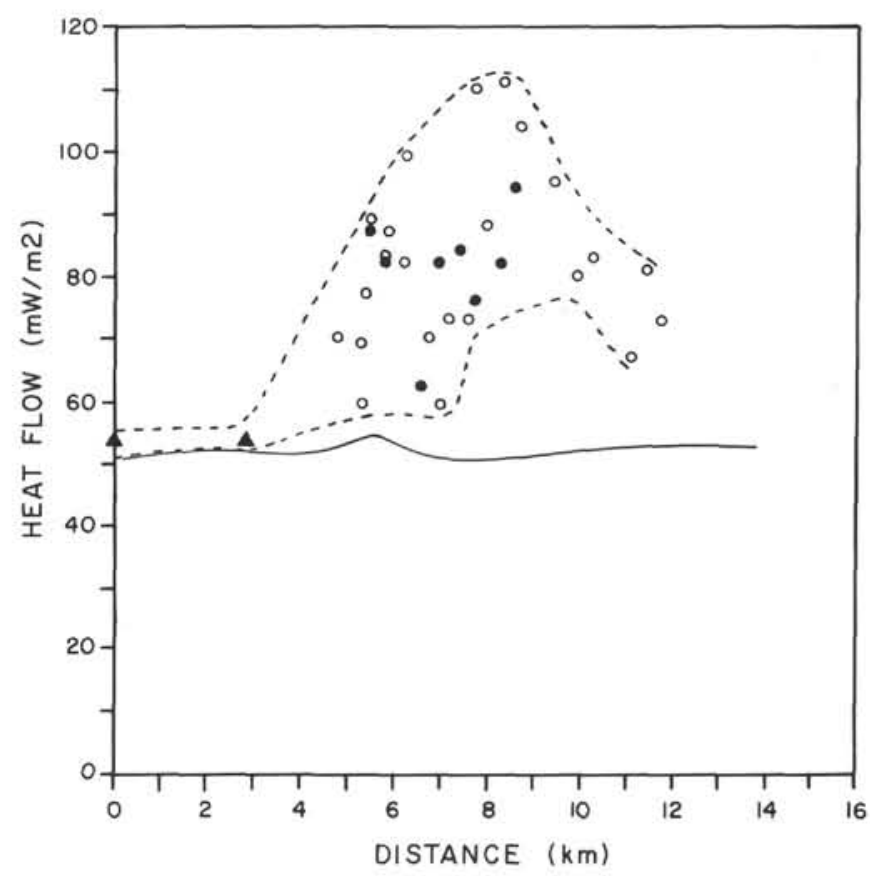

Figure 9. Heat flow profile (solid line) for convection in sediments having a permeability specified by the Kozeny-Carman relationship, compared with site survey heat flow measurements. Solid triangles are measurements from Sites 717 and 719; solid circles are measurements from heat flow stations located along the drilling transect; open circles are measurements from the two adjacent heat flow transects. Dotted lines delineate the range of values from all of the measurements.

tion. Geller et al. (1983) estimated that the fluid flow needed to produce the nonlinear temperature gradients equaled approximately $2 \mathrm{~m} / \mathrm{yr}$, and they suggested that such flow rates were much higher than dewatering sediment could produce. The maximum dewatering rate calculated from average sedimentation and compaction rates at Sites 717,718 , and 719 is

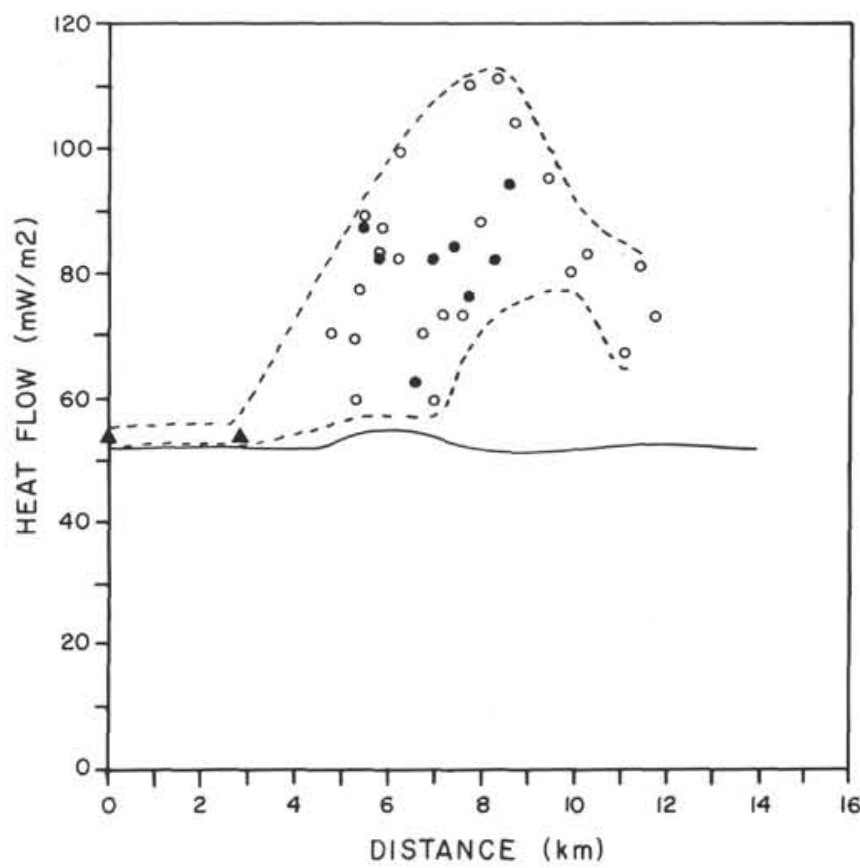

Figure 10. Heat flow profile for sediments with permeability specified by the Kozeny-Carman relationship, except for a buried reverse fault of $10^{-14} \mathrm{~m}^{2}$ permeability. Symbols as in Figure 9. 
approximately $250 \mathrm{~m}$ over $7 \mathrm{~m} . \mathrm{y}$. or $3.6 \times 10^{-5} \mathrm{~m} / \mathrm{yr}$, which confirms the suggestion of Geller and others. However, the absence of nonlinear gradients at most heat flow stations (including all of the site survey stations), leaves open the possibility that concentration of dewatering flow along fractures and fault surfaces may account for a significant portion of the high heat flow.

Sediment deformation and deposition is included in the model through modification of the original PT code. Loading, compaction and dewatering are handled with two separate dynamic approaches. In the first approach, after an incremental sediment load is emplaced, dewatering proceeds according to the porosity-vs.-depth trends measured in situ. The fluid flow system then evolves until there is another deposition event or movement along the faults. The program simulates fault movement at regular $400,000 \mathrm{yr}$ intervals by transferring material properties to a new incrementally evolved mesh geometry. In the second dynamic approach, the weight of each sediment load (and/or any tectonic loads) is resolved into a force on the underlying sedimentary section. The turbiditic sedimentation is essentially instantaneous and episodic, with individual turbidite deposition occurring approximately once every $1000 \mathrm{yr}$ with an average thickness of $0.1 \mathrm{~m}(0.01-2.5 \mathrm{~m}$ range) (Cochran, Stow, et al., 1989). This is modeled through an undrained loading change in pore pressure according to the following equation

$$
\left[\begin{array}{l}
\partial \underline{p} \\
\partial \bar{\sigma}
\end{array}\right]_{M_{f}}=\beta_{\mathrm{r}} /\left(\beta_{\mathrm{r}}+\phi \beta\right)
$$

where $\mathrm{p}$ is the pore pressure, $\sigma$ is the total stress, $\mathrm{M}_{\mathrm{f}}$ is the fluid mass within a given volume, $\beta_{\mathrm{r}}$ is the matrix compressibility, and $\beta$ is the fluid compressibility (Lambe and Whitman, 1969; Narasimhan, pers. comm., 1988). Fluid transport due to this undrained pore pressure generation follows according to Equations 8 and 10. Depending upon the medium's compressibility and permeability, excess pore pressure will either dissipate before the next turbidite deposit arrives or continue to build up with time, leading to undercompaction. For the ranges of permeability and sedimentation rate determined above, the undrained loading results are similar to those obtained by forcing dewatering to follow the measured porosity-depth trend. The sediment dewaters efficiently over 7 m.y., and pore pressures significantly in excess of hydrostatic are not maintained over time.

Figures $12 \mathrm{~A}$ through $12 \mathrm{E}$ display the results of system evolution simulations that end at $7 \mathrm{~m}$.y. with the porosity and permeability structure originally specified for the static case. These simulations include a fault zone permeability of $10^{-14}$ $\mathrm{m}^{2}$. As faulting and folding begin, a sharp $10 \mathrm{~mW} / \mathrm{m}^{2}$ heat flow high appears as the focus of fluid advection (Fig. 12A). The amplitude of this high varies with time, growing as the sediment dewaters vigorously following a period of high sedimentation rates (Fig. 12B) and then decreasing as the sedimentation rate drops (Fig. 12C). Eventually, the heat flow high broadens as Pleistocene sediments bury the fault (compare Figs. 12C and 12D). Results of these dynamic simulations indicate that, while permeable reverse faults will focus sediment dewatering paths to produce a more pronounced heat flow high, the widths and magnitudes of these highs are not large enough to duplicate the observed heat flow.

\section{Permeable Basement Simulations}

All of the simulations discussed above specify an impermeable basement as a lower boundary. Evidence for continued hydrothermal convection in oceanic crust as old as $60 \mathrm{Ma}$ in the Indian Ocean and $70 \mathrm{Ma}$ in the Atlantic Ocean (Ander- son et al., 1977; Anderson et al., 1979) suggests that oceanic crust maintains a significant permeability to great age. This hypothesis is supported by direct observations of high permeability (approximately $10^{-14} \mathrm{~m}^{2}$ ) and fluid flow in DSDP and ODP basement drill holes (Anderson and Zoback, 1982; Becker, Sakai, et al., 1987; Becker, 1989). Reactivation or rejuvenation of crustal convection systems through folding and thrusting of sediments and basement could provide fluid recharge for advection along reverse faults.

Figure 13 depicts the heat flow profile that develops for a fault zone permeability of $10^{-14} \mathrm{~m}^{2}$ if a $500 \mathrm{~m}$ thick layer of permeable $\left(10^{-14} \mathrm{~m}^{2}\right)$ basement is located beneath the sedimentary sequence with the permeability structure specified above. The permeable basement provides a conduit which allows fluid to move between permeable reverse faults. If recharge is available through the basement, the resulting heat flow profile follows the upper range of the site survey heat flow data. Systematically decreasing the overall sediment permeability by a factor of two (Fig. 14) and four (Fig. $15)$ lowers the level of the fault-centered heat flow high down through the envelope of site survey data, providing a general match with the observations. The line connecting the heat flow data recorded along the drilling transect illustrates the small scale (hundreds of meters) variability in heat flow within this region (Figs. 13 through 15). The fluid flow model, as currently configured, does not have the resolution necessary for delineating these details, which probably result from fluid flow along some of the many secondary sediment faults found in the area by a subsequent survey (Bull and Scrutton, pers. comm., 1988). The 1-2 km offset of the modeled heat flow peak from the observed peak also may result from fluid flow along these secondary faults. Alternatively, the two-dimensionality of the model may not represent all of the significant features of the flow system. As Figures 2 and 3 show, neither the thrust fault spacing nor heat flow contours are perfectly two-dimensional.

Although the basement permeability simulations yield a reasonable match to the observations, some difficulties re-

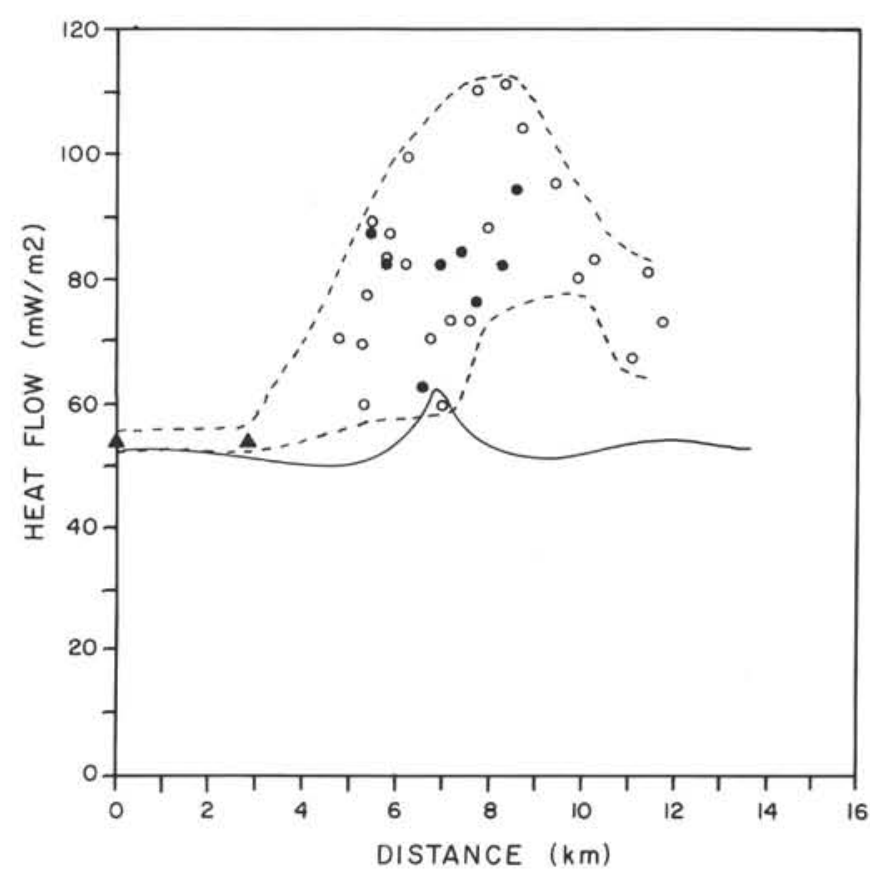

Figure 11. Heat flow profile which results when clay-rich sediment permeability is increased by a factor of 10 . Symbols as in Figure 9. 

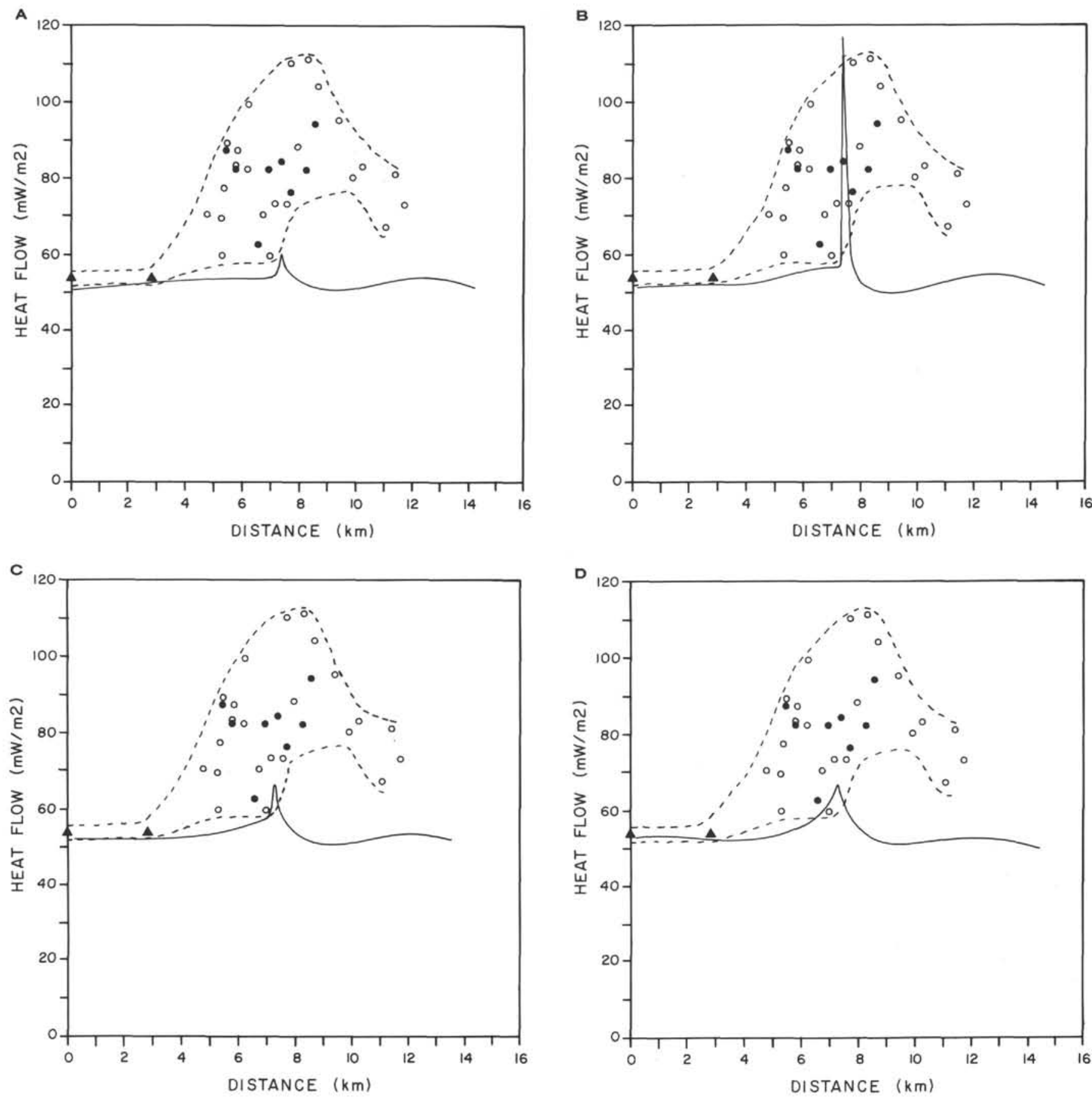

Figure 12. Heat flow profile from dynamic simulation of sedimentation and compaction after (A) 560,000 yr of faulting and deposition, (B) 2.1 m.y., (C) 4.9 m.y., and (D) 7.0 m.y. Symbols as in Figure 9.

main. Most models and observations of convection in the oceanic crust indicate that aspect ratios for the convection cells are in the range of 1-4 (Anderson et al., 1979; Williams et al., 1986), although the depth of active fluid circulation is poorly constrained. If the reactivated convection system in the Leg 116 area shares this same property, then a broad recharge zone should exist within $20 \mathrm{~km}$ of the drill sites. While heat flow data are not available in the immediate vicinity, three measurements by Geller et al. (1983) approximately $160 \mathrm{~km}$ to the south average $125 \mathrm{~mW} / \mathrm{m}^{2}$. In fact, almost all of the heat flow measurements within the intraplate deformation region either equal or exceed the $50-60 \mathrm{~mW} / \mathrm{m}^{2}$ predicted by the cooling plate model. The failure of the data to resolve an obvious recharge zone leaves a cloud of uncertainty over any convection cell model, so other possibilities must be explored.

\section{Lithospheric Reheating Simulations}

The $3 \mathrm{~km}$ proximity of $50 \mathrm{~mW} / \mathrm{m}^{2}$ conductive heat flow to $80+\mathrm{mW} / \mathrm{m}^{2}$ convective heat flow is inconsistent with the long term response of the crust to a deep lithosphere or mantle heating event, as is the absence of any significant departure from the predicted bathymetry for 78 Ma crust (Stein, 1984; Stein and Weissel, 1989). However, since the observations 


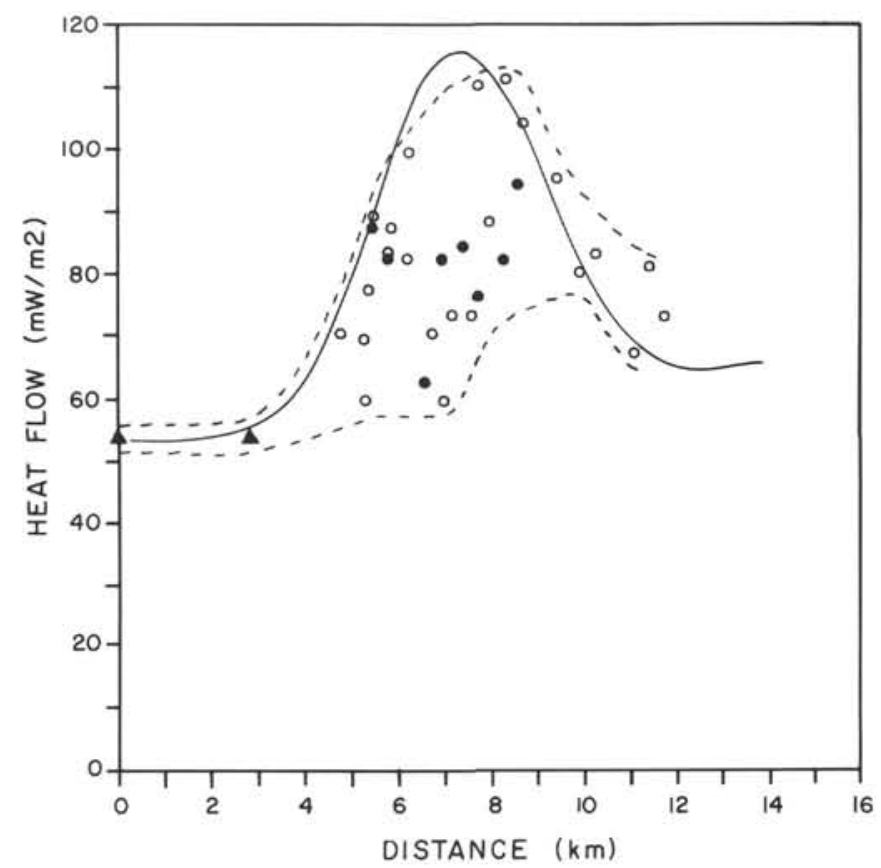

Figure 13. Heat flow profile for the simulation shown in Figure 10 with an added basement permeability of $10^{-14} \mathrm{~m}^{2}$. Symbols as in Figure 9.

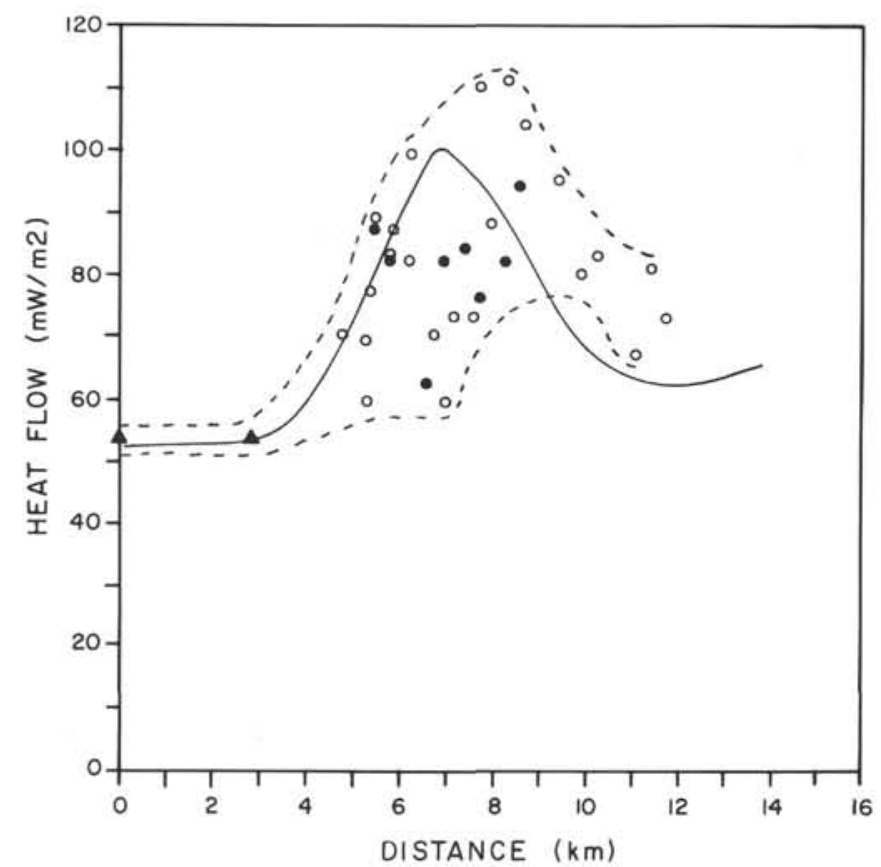

Figure 14. Heat flow profile for the permeable basement simulation of Figure 13 with the overall permeability dropped by a factor of 2 . Symbols as in Figure 9.

and simulations indicate that the reverse faults are high permeability conduits, it is possible that the transient response to a recent reheating event may show high heat flow over the fault zones and normal heat flow in the undeformed sediments.

Figures 16A and 16B illustrate the evolution of surface heat flow in response to a doubling (to $106 \mathrm{~mW} / \mathrm{m}^{2}$ ) of the basal heat flux from the crust. This simulation is based on the standard Kozeny-Carman permeability structure, with a fault perme-

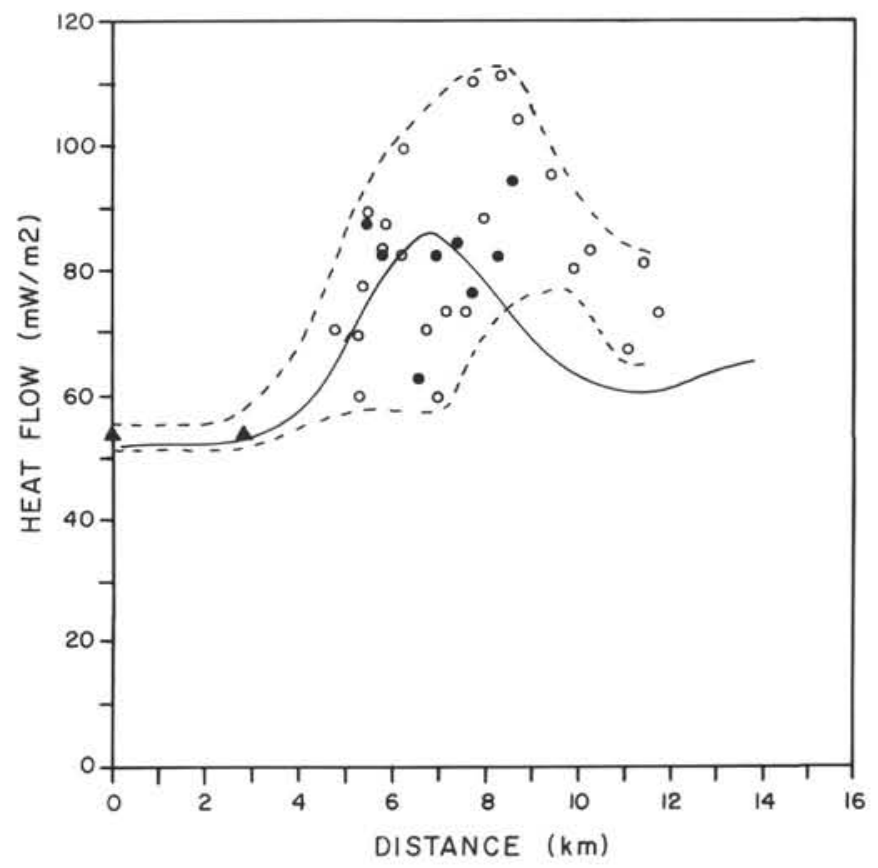

Figure 15. Heat flow profile for the permeable basement simulation of Figure 13 with the overall permeability dropped by a factor of 4 . Symbols as in Figure 9.

ability of $10^{-14} \mathrm{~m}^{2}$. Within $10,000 \mathrm{yr}$ after the initial heating event, vigorous upwelling of pore fluid along the faults results in a sharp, fault-centered heat flow high. This high reaches a value of $80 \mathrm{~mW} / \mathrm{m}^{2}$ by $50,000 \mathrm{yr}$ after reheating (Fig. 16A). After this time, however, the conductive heat flow response begins to develop, with surface heat flow values exceeding 80 $\mathrm{mW} / \mathrm{m}^{2}$ along the surface within $200,000 \mathrm{yr}$ (Fig. 16B).

Given the uncertainties regarding the timing, depth, and amplitude of any lithospheric reheating, these results cannot be considered exact. However, they do illustrate that, if a deep heat source were driving the observed heat flow highs, upper crustal reheating must have started within the last $100,000-200,000 \mathrm{yr}$. Since the start of crustal buckling and faulting was approximately $7-8 \mathrm{Ma}$, the chance that the effects of a reheating event have reached the upper crust within the past $200,000 \mathrm{yr}$ is unlikely. Thus, with all of its limitations, lithospheric reheating is not a likely source of the hydrothermal circulation.

\section{High Fluid Pressure Faulting}

Recently, Sibson et al. (1988) proposed that in continental interiors, high-angle, thrust earthquakes are triggered by the local build up of near-lithostatic pore pressures. This triggering mechanism is thought to explain the apparent violation of Byerlee friction law conditions (Byerlee, 1978) by movement of thrust faults at angles greater than $50^{\circ}$ from the maximum horizontal principal stress. Since the intraplate deformation region is covered with small-scale, high-angle $\left(>70^{\circ}\right)$ reverse faults, perhaps this proposed mechanism may be the driving force behind the fluid advection and high heat flow. Fluid pressure release from within the crust could initiate intermittent flow up through the sedimentary section of the reverse faults without requiring continuous crustal hydrothermal convection.

Upon closer examination, however, the limitations of this approach become apparent. First, there is no clear mechanism for creating high fluid pressure within the crust. This fluid 
A

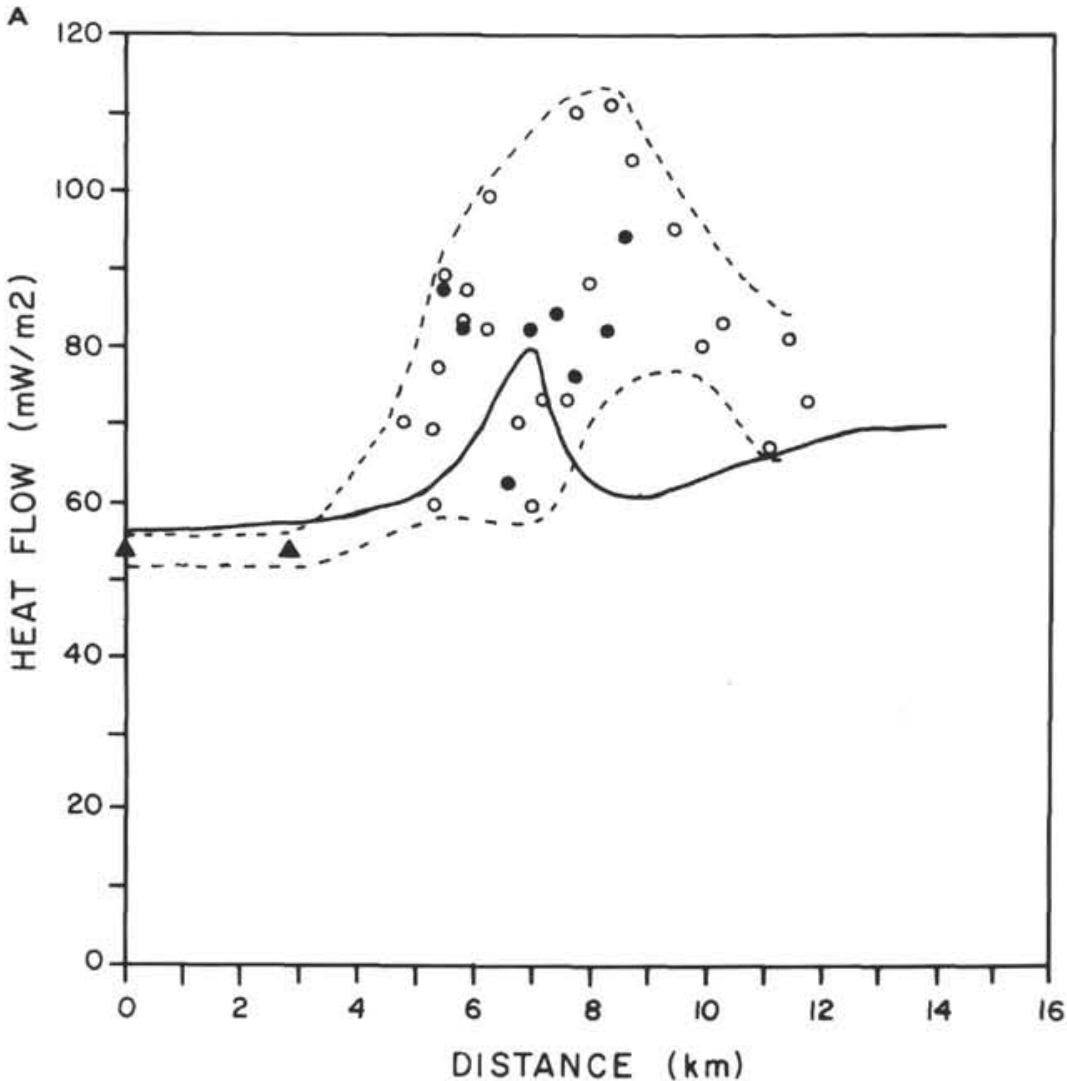

B

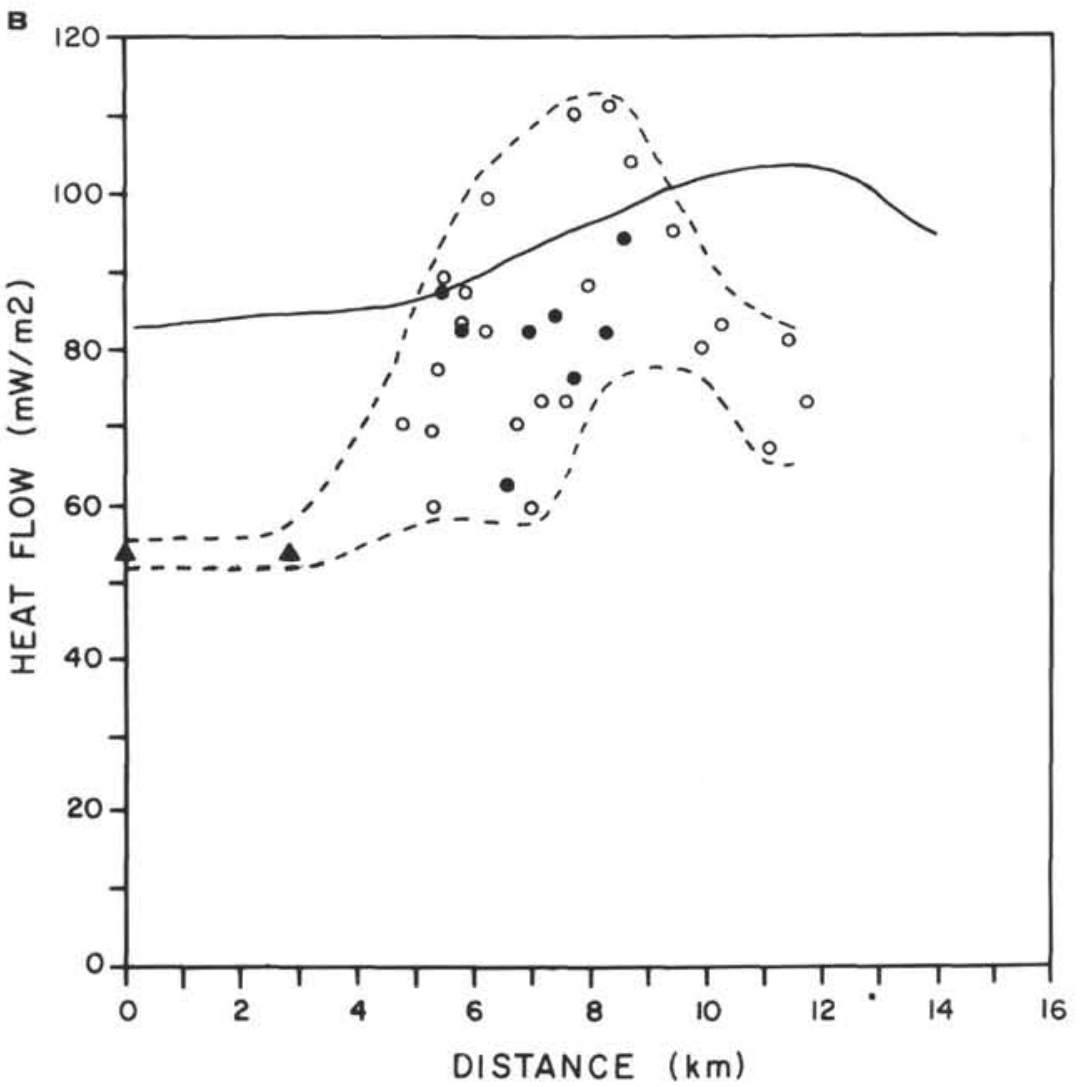

Figure 16. Heat flow profile resulting from the response after (A) 50,000 yr to a doubling of lithospheric heat flow and (B) 200,000 yr. Note the eventual disappearance of the pronounced heat flow high over the buried reverse fault. Symbols as in Figure 9. 
pressure source is not addressed in the Sibson et al. (1988) model, except for a reference to regional metamorphism as a possible source. Second, near-lithostatic pore pressures will enhance fracture permeability, accelerating the immediate expulsion of overpressured fluid along the fault and allowing the system to re-equilibrate before the next fault rupture. Third, the volume of pressurized fluid is unknown, leaving a large uncertainty regarding the amount of fluid that can be expelled under high pressure. The uncertainties inherent in this scenario (unknown changes in permeability, unknown extent of lithostatic pore pressure, unknown fluid volumes) make any attempt at quantitative simulation unworkable. If large volumes of crustal fluids are being pressurized, then a permeable basement must serve as a source of recharge. This leads, ultimately, to a variation on the basement convection system discussed above. Thus, even if high fluid pressure faulting is an important component of the observed hydrothermal circulation, a permeable basement convection system must be feeding fluid to the faults.

\section{CONCLUSIONS}

Results from ODP Leg 116 and the pre-leg site survey yielded comprehensive information about the structural form, history, physical properties, hydraulic properties, chemistry, and thermal state of tilted fault blocks formed through intraplate deformation in the central Indian Ocean. Spatially variable high heat flow (up to $166 \mathrm{~mW} / \mathrm{m}^{2}$ ) associated with reverse faults deviates from the $52 \mathrm{~mW} / \mathrm{m}^{2}$ predicted for $78 \mathrm{Ma}$ crust by cooling plate models of the oceanic lithosphere. Since the pattern of surface heat flow is inconsistent with a steady-state, deep lithospheric heat source, this high heat flow must have a shallow, upper crustal source or reflect a transient response to lithospheric reheating. Evidence from downhole temperatures, interstitial water chemistry, and sediment diagenesis is consistent with hydrothermal flow within faults and deformed sediments.

This integrated data set contains enough quantitative information to serve as input for a mathematical model of heat and fluid flow resulting from the intraplate deformation. If the basal crustal heat flow is specified as $53 \mathrm{~mW} / \mathrm{m}^{2}$, then the only adjustable parameters in the model are the basement permeability and fault zone permeability. If basement is impermeable, low undeformed sediment permeability limits the fluid volume available for circulation to values far below those necessary for reproducing the observed heat flow highs. If basement is permeable $\left(10^{-14} \mathrm{~m}^{2}\right)$, then flow to the reverse faults from the upper crust provides an approximate match with the observed heat flow. However, the reactivation or rejuvenation of basement convection systems requires the presence of low heat flow recharge zones on adjacent fault blocks. Areas having low heat flow $\left(<50 \mathrm{~mW} / \mathrm{m}^{2}\right)$ have not been observed in this region. The introduction of sedimentation and dewatering effects does not significantly alter the surface heat flow pattern over the $7 \mathrm{~m}$.y. evolution of the tilted fault blocks.

An alternative to the permeable basement model, advection of fluid due to recent lithospheric reheating, reproduces the observed heat flow pattern through the rapid response of the permeable deformed sediments to crustal reheating. However, simulation results demonstrate that undeformed sediment heat flow increases significantly within $100,000 \mathrm{yr}$ after upper crustal reheating. The probability of reheating occurring within this recent time interval is quite low.

The possible generation of high pore fluid pressures along the reverse faults is consistent with their high angle orientations $\left(>70^{\circ}\right)$, but the lack of quantitative constraints on the nature, timing, and extent of any anomalous pressurization leaves this possibility untested. In addition, the requirement of high basement permeability remains.

Thus, the simulation results indicate that basement convection is the most likely explanation for the unusually high heat flow. If the basement convection hypothesis is correct, then the extension of detailed heat flow measurements to the surrounding $20 \mathrm{~km}$ should locate a low heat flow recharge zone. The absence of a recharge zone would invalidate the basement convection model and force the rethinking of basic assumptions regarding fluid circulation in the oceanic crust.

\section{ACKNOWLEDGMENTS}

I thank T. N. Narasimhan for sharing his time, expertise, and enthusiasm in the development of the combined fluid and heat flow model. A. Wetzel freely shared his data on sediment physical properties. R. N. Anderson, J. Cochran, and M. Hobart provided thoughtful advice and criticism. Two anonymous reviewers contributed careful, comprehensive reviews. This work was supported by the JOI United States Scientific Advisory Committee (USSAC) through TAMRF Grant No. 20149.

\section{REFERENCES}

Anderson, R. N., Hobart, M. A., and Langseth, 1979. Convective heat transfer in oceanic crust and sediment in the Indian Ocean. Science, 204:828-832.

Anderson, R. N., Langseth, M. G., and Sclater, J. G., 1977. The mechanism of heat transfer through the floor of the Indian Ocean. J. Geophys. Res., 82:3391-3409.

Anderson, R. N., and Zoback, M. D., 1982. Permeability, underpressures, and convection in the oceanic crust near the Costa Rica Rift, eastern equatorial Pacific. J. Geophys. Res., 87:28602868.

Archie, G. E., 1942. The electrical resistivity $\log$ as an aid in determining some reservoir characteristics. Trans. Am. Inst. Min. Metall. Pet. Eng., 146:54-67.

Becker, K., 1989. Measurements of the permeability of the upper oceanic crust at Hole 395A, ODP Leg 109. In Detrick, R., Honnerez, J., Bryan, W. B., Juteau, T., et al., Proc. ODP, Sci. Results, 106/109: College Station, TX (Ocean Drilling Program), 213-222.

Becker, K., Sakai, H., et al., 1988. Proc. ODP, Init. Repts., 111: College Station, TX (Ocean Drilling Program).

Bodvarsson, G. S., 1982. Mathematical modeling of the behavior of geothermal systems under exploitation [Ph.D. dissert.]. Univ. of Calif., Berkeley.

Bourbie, T., Coussy, O., and Zinszner, B., 1987. Acoustics of Porous Media: Houston (Gulf Publ.).

Byerlee, J. D., 1978. Friction of rocks. Pure Appl. Geophys., 116:615-626.

Cochran, J. R., Stow, D.A.V., et al., 1989. Proc. ODP, Init. Repts., 116: College Station, TX (Ocean Drilling Program).

Eittreim, S. L., and Ewing, J., 1972. Midplate tectonics in the Indian Ocean. J. Geophys. Res., 77:6413-6421.

Fehn, U., Green, K. E., Von Herzen, R. P., and Cathles, L.M., 1983. Numerical models for the hydrothermal field at the Galapagos spreading center. J. Geophys. Res., 88:1033-1048.

Geller, C. A., Weissel, J. K., and Anderson, R. N., 1983. Heat transfer and intraplate deformation in the central Indian Ocean. $J$. Geophys. Res., 88:1018-1032.

Gieskes, J., et al., in press. Hydrogeochemistry in the Barbados Accretionary Complex: ODP Leg 110. Tectonophysics.

Jarrard, R. D., Dadey, K. A., and Busch, W. H., 1989. Velocity and density of sediments of Eirik Ridge, Labrador Sea: control by porosity and mineralogy. In Srivastava, S. P., Arthur, M. A., Clement, B., et al., Proc. ODP, Sci. Results, 105: College Station, TX (Ocean Drilling Program), 811-835.

Lambe, T. W., and Whitman, R. V., 1969. Soil Mechanics: New York (Wiley). 
Langseth, M. G., Westbrook, G. K., and Hobart, M. A., 1988. Geophysical survey of a mud volcano seaward of the Barbados Ridge accretionary complex. J. Geophys. Res., 93:1049-1061.

Macdonald, K. C., Becker, K., and Speiss, F. N., 1980. Hydrothermal heat flux of black smoker vents on the East Pacific Rise. Earth Planet. Sci. Lett., 48:1-7.

Mascle, A., Moore, J. C., et al., 1988. Proc. ODP, Init. Repts., 110: College Station, TX (Ocean Drilling Program).

Narasimhan, T. N., and Witherspoon, P. A., 1976. An integrated finite difference method for analyzing fluid flow in porous media Water Resour. Res., 12:57-64.

Palciauskas, V. V., 1986. Models for thermal conductivity and permeability in normally compacting basins. In Burrus, J. (Ed.), Thermal Modeling in Sedimentary Basins, Paris (Editions Technip), 323-336.

Parsons, B., and Sclater, J. G., 1977. An analysis of the variation of oceanic bathymetry and heat flow with age. J. Geophys. Res. 82:803-827.

Raymer, L. L., Hunt, E. R., and Gardner, J. S., 1980. An improved sonic transit time-to-porosity transform. Trans. SPWLA 2lst Annu. Log. Symp., Paper P.

Serra, O., 1984. Fundamentals of Well Log Interpretation: Amsterdam (Elsevier).

Sibson, R. H., Barstow, N., and Boatwright, J., 1988. Fluid pressure triggering of high-angle reverse intraplate earthquakes, EOS Trans. Am. Geophys. Union, 44:1448.

Stein, C. A., 1984. Heat transfer, seismicity and intraplate deformation in the central Indian Ocean-Part I [Ph.D. Dissert.]. Columbia Univ., New York.
Stein, C. A., and Weissel, J. K., in press. Constraints on Central Indian Basin thermal structure from heat flow, seismicity, and bathymetry. Tectonophysics.

Stein, S., and Okal, E. A., 1978. Seismicity and tectonics of the Ninetyeast Ridge area: evidence for internal deformation of the Indian plate. J. Geophys. Res., 83:2233-2245.

Tsang, C. F., and Doughty, C., 1985. Detailed validation of liquid and heat flow code against field performance. 5th Symp. on Reservoir Simulation.

Weissel, J. K., Anderson, R. N., and Geller, C. A., 1980. Deformation of the Indo-Australian plate. Nature, 287:284-291.

Williams, C. F., Narasimhan, T. N., Anderson, R. N., Zoback, M. D., and Becker, K., 1986. Convection in the oceanic crust: simulation of observations from Deep Sea Drilling Project Hole 504B, Costa Rica Rift. J. Geophys. Res., 91:4877-4889.

Williams, C. F., and Narasimhan, T. N., 1989. Hydrogeologic constraints on heat flow along the San Andreas fault: a testing of hypotheses, Earth Planet. Sci. Lett., 92:131-143.

Williams, D. L., Von Herzen, R. P., Sclater, J. G., and Anderson, R. N., 1974. The Galapagos spreading centre: lithospheric cooling and hydrothermal circulation. Geophys. J.R. Astron. Soc., 38:587-608.

Yamano, M., and Uyeda, S., 1988. Heat flow in the ocean basins and margins. In Nairn, A.E.M., Stehli, F. G., and Uyeda, S. (Eds.), The Ocean Basins and Margins (Vol. 7): New York (Plenum), 523-557.

Date of initial receipt: 14 March 1989

Date of acceptance: 6 February 1990

Ms 116B-139 